\title{
Anaerobic ammonium oxidation (anammox) in sediments of the Gulf of Finland
}

\author{
Susanna Hietanen* \\ Department of Biological and Environmental Sciences, Division of Aquatic Sciences, University of Helsinki, \\ PO Box 65, 00014 University of Helsinki, Finland
}

\begin{abstract}
Anaerobic ammonium oxidation (anammox) and denitrification were measured in the open sea and coastal accumulation basins of the Gulf of Finland. The different methods used gave conflicting results on the importance of the anammox process in the sediments. Anammox generally contributed less than $20 \%$ to the total $\mathrm{N}_{2}$ production, and no anammox was found in a shallow inner estuary basin. However, the discovery of the anammox process in the open sea sediments challenges the denitrification measurements made in the area, as the coexistence of anammox and denitrification compromises the central assumptions behind the method used in denitrification measurements and causes overestimates of the $\mathrm{N}_{2}$ production. The high ${ }^{15} \mathrm{NO}_{3}{ }^{-}$incubation concentration used in Baltic Sea denitrification measurements exacerbates this overestimation, which is likely to have been substantial.
\end{abstract}

KEY WORDS: Denitrification - Anaerobic ammonium oxidation · Anammox · Nitrogen cycling · Baltic Sea Resale or republication not permitted without written consent of the publisher

\section{INTRODUCTION}

The Baltic Sea is among the largest brackish water basins in the world. It features several special characteristics, including a surface salinity range of 2 to 20 due to extensive river discharge in the north and a connection to the North Sea in the south, severe salinity stratification with limited water exchange between the layers, and seasonal thermal stratification with surface temperatures ranging from ice cover in winter to more than $20^{\circ} \mathrm{C}$ in mid-summer. The Baltic Sea is one of the most eutrophied marine waters in Europe, and recently a self-sustaining 'vicious circle' has been suggested to operate there (Vahtera et al. 2007). In this concept, the internal loading of phosphorus (P) from anoxic sediments lowers the nitrogen $(\mathrm{N})$ to $\mathrm{P}$ ratio in the surface waters and thereby promotes the growth of $\mathrm{N}$-fixing cyanobacteria in late summer. Outside the growing season, the mineralization of these bacteria releases fixed $\mathrm{N}$, which is used during spring blooms. The heavy spring algae (mainly diatoms) settle to the sea floor, and their mineralization consumes oxygen, further increasing the internal P loading from the sediments. The internal loading counteracts the efforts to control eutrophication by reducing the external load (Pitkänen et al. 2001). The easternmost arm of the Baltic Sea, the Gulf of Finland, is its most eutrophied sub-basin (HELCOM 2002). The gulf is directly connected to the Baltic Proper at its western end and is under the influence of the River Neva at the eastern end. In the easternmost part of the gulf, primary production is limited by $\mathrm{P}$ availability, whereas the central and western parts are N limited (Kivi et al. 1993, Pitkänen \& Tamminen 1995). Annually, ca. $120000 \mathrm{t}$ of $\mathrm{N}$ enter the Gulf of Finland (Kiirikki et al. 2003). A major sink for the $\mathrm{N}$ loading is benthic denitrification, a microbial process in which nitrate is sequentially reduced to nitrogen gas: 


$$
2 \mathrm{NO}_{3}{ }^{-}+10 \mathrm{e}^{-}+12 \mathrm{H}^{+}=\mathrm{N}_{2}+6 \mathrm{H}_{2} \mathrm{O}
$$

Denitrification has been studied in the open sea accumulation bottoms of the gulf, and about $45000 \mathrm{t} \mathrm{N}$, corresponding to about $40 \%$ of the annual $\mathrm{N}$ loading, has been calculated to be removed by denitrification (Tuominen et al. 1998). Earlier, denitrification was seen as the only process that removed fixed $\mathrm{N}$ from the water ecosystem. A decade ago, another $\mathrm{N}$-removing process, anaerobic ammonium oxidation (anammox), was discovered in wastewater treatment plants (Mulder et al. 1995, Van de Graaf et al. 1995), and later also in marine sediments (Dalsgaard \& Thamdrup 2002, Thamdrup \& Dalsgaard 2002, Trimmer et al. 2003). In this process, microbes oxidise ammonium with nitrite to form nitrogen gas:

$$
\mathrm{NO}_{2}^{-}+\mathrm{NH}_{4}{ }^{+}=\mathrm{N}_{2}+2 \mathrm{H}_{2} \mathrm{O}
$$

The accumulating knowledge about the process and the microbes responsible for it has recently been excellently reviewed by Dalsgaard et al. (2005). In marine sediment, both $\mathrm{N}$-removing processes can proceed at the same time. The coexistence of anammox and denitrification, however, compromises the central assumptions behind the method used in denitrification measurements, the isotope pairing technique (IPT; Nielsen 1992). The IPT is based on calculating the production of ${ }^{14} \mathrm{~N}^{14} \mathrm{~N}$ pairs from the production of ${ }^{14} \mathrm{~N}^{15} \mathrm{~N}$ and ${ }^{15} \mathrm{~N}^{15} \mathrm{~N}$ pairs in the presence of known amounts of natural ${ }^{14} \mathrm{NO}_{3}{ }^{-}$and added ${ }^{15} \mathrm{NO}_{3}{ }^{-}$, assuming random pairing of the isotopes. The formation of ${ }^{14} \mathrm{~N}^{14} \mathrm{~N}$ pairs is assumed to be independent from the ${ }^{15} \mathrm{NO}_{3}{ }^{-}$concentration used in the incubation, and the production of the ${ }^{14} \mathrm{~N}^{14} \mathrm{~N},{ }^{14} \mathrm{~N}^{15} \mathrm{~N}$ and ${ }^{15} \mathrm{~N}^{15} \mathrm{~N}$ pairs is assumed to follow a binomial distribution. In the presence of ${ }^{15} \mathrm{NO}_{3}{ }^{-}$and ${ }^{14} \mathrm{NH}_{4}{ }^{+}$, the anammox process produces ${ }^{14} \mathrm{~N}^{15} \mathrm{~N}$, leading to violations of the assumptions of concentration independency and binomial distribution of the products. Thus, the coexistence of anammox and denitrification leads to overestimates of the $\mathrm{N}_{2}$ production when measured using the IPT, and the magnitude of the error is related to the ${ }^{15} \mathrm{NO}_{3}{ }^{-}$concentration used in the incubation. Anammox was recently found at a coastal station in the northern Gulf of Finland (Hietanen \& Kuparinen in press). Had the anammox not been taken into account, the $\mathrm{N}_{2}$ production would have been overestimated by $50 \%$, even though anammox contributed only 10 to $15 \%$ to the total $\mathrm{N}_{2}$ production (Hietanen \& Kuparinen in press). From these findings arose a need to evaluate the validity of the denitrification estimates calculated for the Gulf of Finland, using the IPT, before the discovery of the anammox process.

Two techniques are currently used to estimate the contribution of anammox to the total $\mathrm{N}_{2}$ production in sediments where both processes exist. In the first technique, a revised IPT (r-IPT), parallel series of intact samples from the same site are incubated with different concentrations of ${ }^{15} \mathrm{NO}_{3}{ }^{-}$. The true ${ }^{14} \mathrm{~N}^{14} \mathrm{~N}$ production rate is calculated using the production rates of ${ }^{14} \mathrm{~N}^{15} \mathrm{~N}$ and ${ }^{15} \mathrm{~N}^{15} \mathrm{~N}$ pairs in the different concentrations and the ratios between the concentrations (RisgaardPetersen et al. 2003, 2004). In the other technique, the nitrate-consuming anoxic sediment layer is sampled, slurried, and divided into 3 different isotopic enrichment treatments $\left({ }^{15} \mathrm{NH}_{4}{ }^{+},{ }^{15} \mathrm{NH}_{4}{ }^{+}\right.$combined with ${ }^{14} \mathrm{NO}_{3}{ }^{-}$, and ${ }^{15} \mathrm{NO}_{3}{ }^{-}$). The relative contribution of anammox to the overall $\mathrm{N}_{2}$ production is calculated from the ratios of ${ }^{29} \mathrm{~N}_{2}$ and ${ }^{30} \mathrm{~N}_{2}$ produced (Thamdrup \& Dalsgaard 2002). The site-specific, intact core r-IPT gives the best estimates of the in situ anammox and denitrification activity because it does not require the destruction of the natural stratification in the sediment. It also measures the activity of the whole sediment core instead of a selected layer. However, it requires minimal sediment heterogeneity, as high scatter in the raw data can mask significant differences in rates (Trimmer et al. 2006). The slurry incubation technique is based on collecting the active layer of sediment, thus breaking the chemical stratification of the sediment, and the processes are not necessarily measured in the layer in which they are at their most active. Therefore, it is prone to underestimating anammox and consequently overestimating the true $\mathrm{N}_{2}$ production rate (Trimmer et al. 2006). However, it has been the only option for measuring anammox in sediments that show high heterogeneity, preventing the use of the intact core technique. A new direct technique was only recently developed based on ${ }^{15} \mathrm{~N}$ labelling of the $\mathrm{N}_{2} \mathrm{O}$ that is produced as an intermediate in denitrification, but not anammox (Trimmer et al. 2006). This novel application of the IPT enables denitrification and anammox in intact cores to be measured even in highly heterogeneous sediments.

This study presents results from $\mathrm{N}_{2}$ production measurements, made using the r-IPT and slurry approaches, from the Gulf of Finland.

\section{MATERIALS AND METHODS}

Intact core measurements 1997. Tuominen et al. (1998) used the IPT to measure denitrification in the Gulf of Finland, at Stn JML at the entrance to the gulf and Stn GF2 in the central gulf, in July 1997 (Table 1). Measurements were made at different ${ }^{15} \mathrm{NO}_{3}{ }^{-}$concentrations, and some of the results have been published (Tuominen et al. 1998). However, the incubation concentration dependency of the D14 $\left(\mathrm{N}_{2}\right.$ production based on the naturally occurring nitrate) estimate was 
Table 1. Characteristics of the sampling stations. Temperature, salinity, $\mathrm{NO}_{\mathrm{x}}{ }^{-}$concentration and oxygen concentration in the bottom water; TC, TN, TS: total carbon, nitrogen and sulphur content, respectively, in the topmost $1 \mathrm{~cm}$ of sediment

\begin{tabular}{|lccccccccccc|}
\hline Stn & Time & $\begin{array}{c}\text { Lat. } \\
\left({ }^{\circ}\right)\end{array}$ & $\begin{array}{c}\text { Long. } \\
\left({ }^{\circ} \mathrm{E}\right)\end{array}$ & $\begin{array}{c}\text { Depth } \\
(\mathrm{m})\end{array}$ & $\begin{array}{c}\text { Temp. } \\
\left({ }^{\circ} \mathrm{C}\right)\end{array}$ & $\begin{array}{c}\text { Salinity } \\
\mathrm{NO}_{2}{ }^{-}+\mathrm{NO}_{3}{ }^{-} \\
(\mu \mathrm{M})\end{array}$ & $\begin{array}{c}\mathrm{O}_{2} \\
(\mu \mathrm{M})\end{array}$ & $\begin{array}{c}\mathrm{TC}_{(\mathrm{g} \mathrm{kg}}^{-1} \\
\mathrm{DW})\end{array}$ & $\begin{array}{c}\mathrm{TN}_{(\mathrm{g} \mathrm{kg}}^{-1} \\
\mathrm{DW})\end{array}$ & $\begin{array}{c}\mathrm{TS}_{(\mathrm{g} \mathrm{kg}}{ }^{-1} \\
\mathrm{DW})\end{array}$ \\
\hline JML & Jul 97 & 59.3515 & 23.3776 & 83 & 3.8 & 9.1 & 10.6 & & & \\
GF2 & Jul 97 & 59.5049 & 25.5158 & 85 & 3.8 & 9.0 & 11.2 & & & \\
GF2-B & Apr 04 & 59.5031 & 25.5141 & 85 & 4.9 & 9.5 & 8.1 & 34 & 77.5 & 9.2 & 10.9 \\
GF2-K & Apr 04 & 59.5047 & 25.5231 & 83 & 4.9 & 9.5 & 7.5 & 42 & 73.1 & 8.5 \\
AHLA & Aug 04 & 60.2412 & 26.2973 & 13 & 7.6 & 4.3 & 3.7 & 200 & 53.2 & 6.1 & 05.4 \\
\hline
\end{tabular}

not statistically analysed or discussed. I was permitted to use the original data to analyse the concentration dependency and, as some of the results showed significant dependency, to recalculate the denitrification estimates using the r-IPT.

Intact core and slurry measurements 2004. In 2004, denitrification and anammox were measured at 2 neighbouring stations in the central Gulf of Finland (Stns GF2-B and GF2-K, in April) and at a coastal station in the northern Gulf of Finland (Stn AHLA, in August; Table 1). Sediment samples were taken with a Gemax twin corer (inner core diameter $9 \mathrm{~cm}$ ).

For r-IPT, 3 sets of 3 replicate subsamples were collected in clear plastic (acrylic) cores (diameter $2.6 \mathrm{~cm}$, height $9 \mathrm{~cm}$ ) by taking 3 subsamples from each of 3 Gemax cores and dividing these in different treatments by using a randomised block design. About half of the subsample core was filled with the sediment and half with the water from above. Samples were enriched with $\mathrm{K}^{15} \mathrm{NO}_{3}$ (98 atom\%, Cambridge Isotope Laboratories) to final concentrations of 50, 100 and $200 \mu \mathrm{m}{ }^{15} \mathrm{NO}_{3}{ }^{-}$in the overlying water, and incubated with a magnetic stirrer on the lid of the cores at in situ temperature in darkness for $3 \mathrm{~h}$. The biological activity in the samples was terminated by adding $1 \mathrm{ml}$ of $100 \%$ $\mathrm{ZnCl}_{2}$, and the samples were carefully mixed with a glass rod. Subsamples of the slurry were transferred to gas-tight $12 \mathrm{ml}$ vials (Exetainer, Labco) into which $250 \mu \mathrm{l} 100 \% \mathrm{ZnCl}_{2}$ were pipetted beforehand. These were sent in to the National Environmental Research Institute, Silkeborg, Denmark (NERI), for analysis of $\mathrm{N}_{2}$ isotopic composition.

For slurry measurements, sediment from 3 replicate cores was combined. All handling of the sediment was done under an $\mathrm{N}_{2}$ atmosphere. The top $0.5 \mathrm{~cm}$ of surface sediment, which is the depth of the $\mathrm{NO}_{3}{ }^{-}$peak in the sediment (Mäkelä \& Tuominen 2003), was removed from the cores, and the next $2 \mathrm{~cm}$ were collected, giving $380 \mathrm{ml}$ of sediment altogether. The collected sediment was slurried with $380 \mathrm{ml}$ of nutrient-free, anoxic ( $\mathrm{N}_{2}$-bubbled) artificial seawater (Reef Crystals, Aquarium Systems) of the same salinity as the bottom water at the study site
(10 psu at the central and 5 psu at the coastal stations). The slurry was divided into 3 batches, which were enriched to a final concentration of (1) $300 \mu \mathrm{M}$ ${ }^{15} \mathrm{NH}_{4} \mathrm{Cl}$ (98 atom\%, Sigma-Aldrich), (2) $300 \mu \mathrm{M}$ ${ }^{15} \mathrm{NH}_{4} \mathrm{Cl}$ and (3) $100 \mu \mathrm{M} \mathrm{K}{ }^{14} \mathrm{NO}_{3}$, and $100 \mu \mathrm{m} \mathrm{K}{ }^{15} \mathrm{NO}_{3}$ (98 atom\%, Cambridge Isotope Laboratories). The enriched slurries were divided into gas-tight, glass centrifuge tubes $(30 \mathrm{ml})$ and incubated at in situ temperature in darkness. A sample of slurry was taken before and 1 sample from each batch right after adding the isotopes. Thereafter, 1 sample from each batch was taken at approximately 1, 6, 18 and $24 \mathrm{~h}$ from the beginning of incubation. The samples were centrifuged $\left(10 \mathrm{~min}, 800 \mathrm{rpm}[135 \times g]\right.$ ), and for $\mathrm{N}_{2}$ isotopic composition analysis, $5.9 \mathrm{ml}$ of supernatant were transferred to gas-tight vials (Exetainer, Labco) and $100 \mu \mathrm{ZnCl}_{2}(100 \%)$ were added. Next, $2 \mathrm{ml}$ of supernatant were filtered (pre-washed Acrodisc Supor 0.8/0.2 $\mu \mathrm{m}, 32 \mathrm{~mm}$, Pall Life Sciences) into a plastic test tube and frozen until the analysis of the isotope labelling of the $\mathrm{NH}_{4}{ }^{+}$pool. The isotope analyses were performed at NERI. The rest of the supernatant was filtered (pre-washed Acrodisc Supor 0.8/0.2 $\mu \mathrm{m}, 32 \mathrm{~mm}$, Pall Life Sciences) and used for nutrient measurements. Ammonium was measured spectrophotometrically according to Koroleff (1983), and combined $\mathrm{NO}_{2}{ }^{-} / \mathrm{NO}_{3}{ }^{-}$was measured using a biosensor (Unisense) calibrated in increasing $\mathrm{NO}_{3}{ }^{-}$ concentration series prepared in nutrient-free artificial seawater (Reef Crystals, Aquarium Systems) of the same salinity as the samples.

\section{RESULTS}

\section{Revised isotope pairing technique}

In July 1997, the denitrification estimate was concentration dependent at both of the stations studied (ANOVA, Stn JML $\mathrm{p}=0.04$, Stn GF2 $\mathrm{p}=0.01$; Fig. 1). At the entrance to the Gulf of Finland (Stn JML), the denitrification estimate varied from 50 to $220 \mu \mathrm{mol} \mathrm{N}$ $\mathrm{m}^{-2} \mathrm{~d}^{-1}$ when calculated using the IPT. Recalculating 

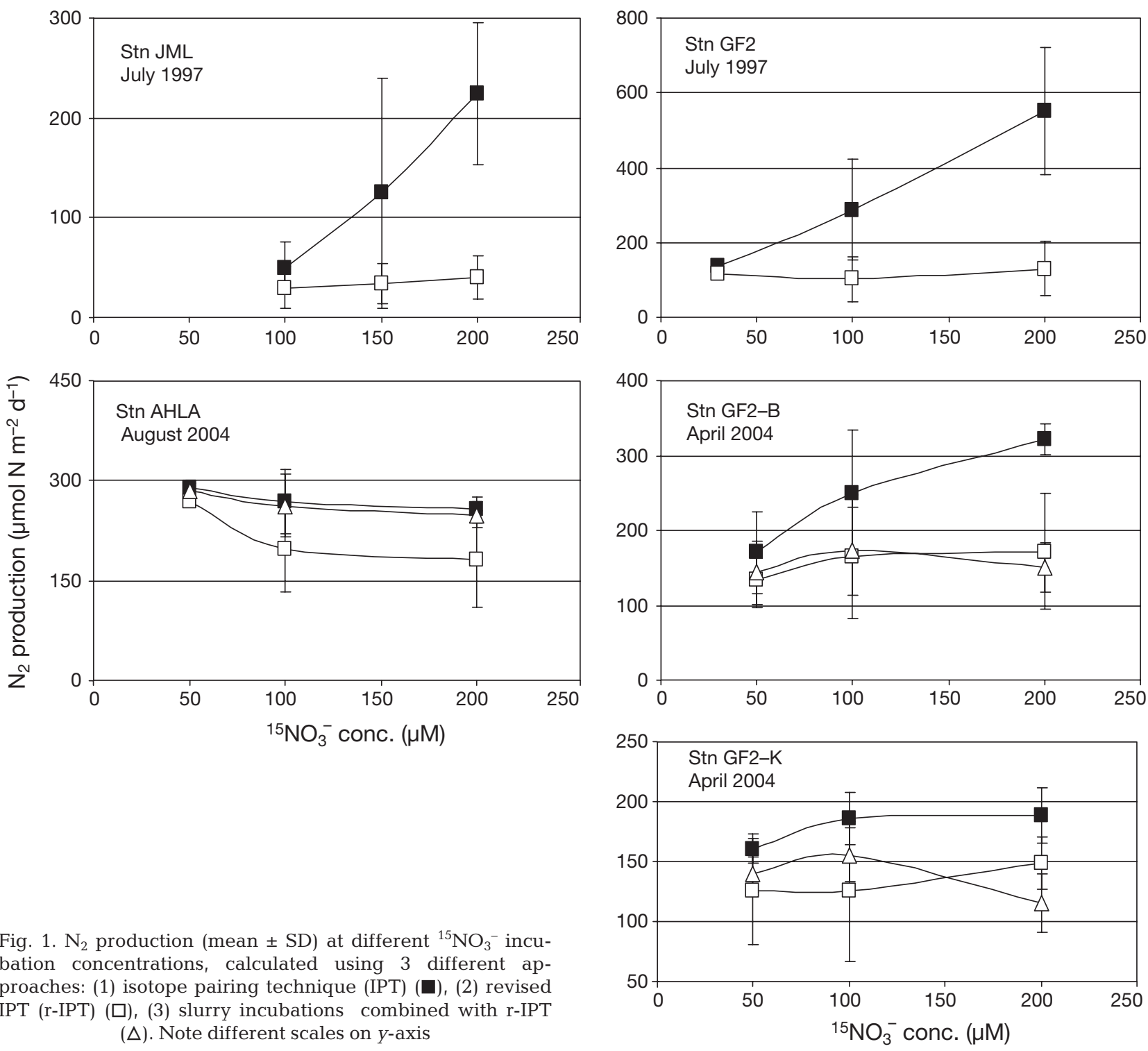

Fig. 1. $\mathrm{N}_{2}$ production (mean $\pm \mathrm{SD}$ ) at different ${ }^{15} \mathrm{NO}_{3}{ }^{-}$incubation concentrations, calculated using 3 different approaches: (1) isotope pairing technique (IPT) (ם), (2) revised IPT (r-IPT) ( $\square)$, (3) slurry incubations combined with r-IPT $(\Delta)$. Note different scales on $y$-axis

the results using the r-IPT, using all possible permutations, lowered the estimate and narrowed its range to 30-40 $\mu \mathrm{mol} \mathrm{N} \mathrm{m}{ }^{-2} \mathrm{~d}^{-1}$ (Fig. 1). In the central Gulf of Finland (Stn GF2), the IPT gave rates that varied between 135 and $550 \mu \mathrm{mol} \mathrm{N} \mathrm{m}^{-2} \mathrm{~d}^{-1}$. The r-IPT decreased the estimate and reduced the variation to 100-130 $\mu \mathrm{mol} \mathrm{N} \mathrm{m} \mathrm{N}^{-2} \mathrm{~d}^{-1}$ (Fig. 1).

In April 2004, no statistically significant concentration dependency was found at Stns GF2-B and GF2-K (randomised blocks ANOVA, $\mathrm{p}=0.10$ and 0.25). To compare the techniques, the results were recalculated using the r-IPT. The classical IPT resulted in rates of 170 to 320 and 160 to $190 \mu \mathrm{mol} \mathrm{N} \mathrm{m} \mathrm{N}^{-1}$ for these 2 stations, and the r-IPT gave estimates that ranged from 130 to 170 and 125 to $150 \mu \mathrm{mol} \mathrm{N} \mathrm{m}{ }^{-2} \mathrm{~d}^{-1}$, respectively (Fig. 1).

At the coastal station located inside an estuary (Stn AHLA), no concentration dependency in the denitrification estimate was detected in August 2004 (randomised blocks ANOVA, $p=0.48$ ). Denitrification estimates varied from 260 to $290 \mu \mathrm{mol} \mathrm{N} \mathrm{m}^{-2} \mathrm{~d}^{-1}$. To compare the techniques, the results were recalculated. However, the slightly decreasing values along with the increasing concentration in the original data complicated the calculations, producing negative results in the calculations. When these were omitted from the data, the new estimates varied between 180 and $270 \mu \mathrm{mol} N$ $\mathrm{m}^{-2} \mathrm{~d}^{-1}$, and the standard deviation was high (Fig. 1). The contribution of anammox was calculated to range from 4 to $9 \%$, which clearly was an artefact resulting from omitting the negative results in the calculations, as no other evidence of anammox could be found. 


\section{Slurry technique}

At Stns GF2-B and GF2-K, the added $\mathrm{NO}_{3}{ }^{-}$was used very fast, and less than $10 \mu \mathrm{m} \mathrm{NO}{ }^{-}$was measured in the samples $6 \mathrm{~h}$ after addition (Fig. 2). Only the samples with measurable concentrations of $\mathrm{NO}_{\mathrm{x}}{ }^{-}$ were taken into account in the calculations. In the incubations with ${ }^{15} \mathrm{NH}_{4}{ }^{+}$and no $\mathrm{NO}_{\mathrm{x}}{ }^{-}$, neither production of labelled $\mathrm{N}_{2}$ nor assimilation of the labelled ammonium was detected. The same held true for the samples incubated with ${ }^{15} \mathrm{NH}_{4}{ }^{+}$and unlabelled $\mathrm{NO}_{\mathrm{x}}^{-}$, indicating a lack of anammox process in the samples However, in the samples enriched with ${ }^{15} \mathrm{NO}_{3}{ }^{-}$, the contribution of anammox to the total $\mathrm{N}_{2}$ production (ra), was calculated to be $17 \%$ at Stn GF2-B and $7 \%$ at Stn GF2-K. These estimates of ra were used to recalculate the results from the intact core incubations made at the different ${ }^{15} \mathrm{NO}_{3}{ }^{-}$concentrations. In both cases, the recalculated $\mathrm{N}_{2}$ production rates were independent of the incubation concentration and showed lower averages than the estimates made using the IPT (Fig. 1).
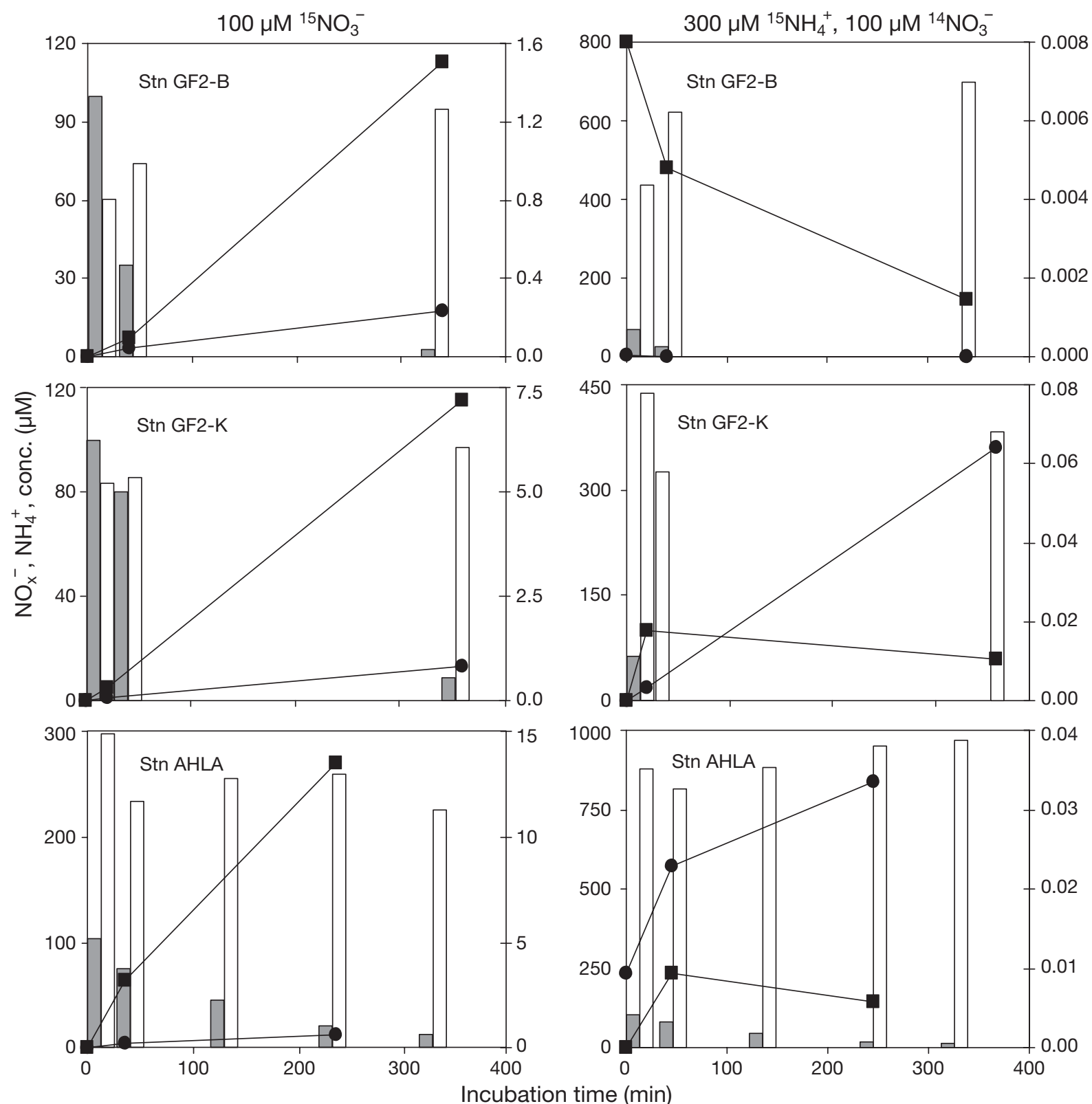

Fig. 2. Concentrations of $\mathrm{NO}_{\mathrm{x}}{ }^{-}$(combined $\mathrm{NO}_{3}{ }^{-}$and $\mathrm{NO}_{2}{ }^{-}$) and $\mathrm{NH}_{4}{ }^{+}$(grey and white columns, respectively, and of ${ }^{29} \mathrm{~N}_{2}$ and ${ }^{30} \mathrm{~N}_{2}$ ( and $\bullet$, respectively) in the slurry incubations with added ${ }^{15} \mathrm{NO}_{3}^{-}$(left-hand panels) and with added ${ }^{15} \mathrm{NH}_{4}{ }^{+}$and ${ }^{14} \mathrm{NO}_{3}{ }^{-}$ (right-hand panels). Note different scales on $y$-axes 
At the inner estuary station, all $\mathrm{NO}_{\mathrm{x}}^{-}$was used after $16 \mathrm{~h}$ of incubation. Very low amounts of ${ }^{29} \mathrm{~N}_{2}$ were produced in the incubations with ${ }^{15} \mathrm{NH}_{4}{ }^{+}$and unlabelled $\mathrm{NO}_{\mathrm{x}}{ }^{-}$. Neither production of labelled $\mathrm{N}_{2}$ nor assimilation of the labelled ammonium was detected when incubating the samples with ${ }^{15} \mathrm{NH}_{4}{ }^{+}$without $\mathrm{NO}_{\mathrm{x}}{ }^{-}$ addition. In the samples enriched with ${ }^{15} \mathrm{NO}_{3}{ }^{-}$, the production of ${ }^{30} \mathrm{~N}_{2}$ clearly dominated the $\mathrm{N}_{2}$ production (Fig. 2), and the contribution of anammox to the total $\mathrm{N}_{2}$ production was calculated to be $0.9 \%$. This estimate of ra was used to recalculate the results from the intact core incubations, but as the contribution of anammox to the total $\mathrm{N}_{2}$ production was minimal, the new $\mathrm{N}_{2}$ production estimate did not differ from the IPT denitrification estimate (Fig. 1).

\section{DISCUSSION}

\section{Anammox in Gulf of Finland sediments: conflicting experimental data}

In July 1997 measurements, concentration dependency of D14 was detected at both open sea stations (Stns GF2 and JML) studied. Using the r-IPT removed the concentration dependency, indicating anammox activity. In April 2004, D14 showed no significant concentration dependency at the open sea stations GF2-B and GF2-K, but when $\mathrm{N}_{2}$ production was recalculated according to r-IPT, anammox was found to contribute up to $20 \%$ of the total $\mathrm{N}_{2}$ production. This could reflect sediment heterogeneity shown in the high standard deviation in the original results, concealing the significant differences and causing variation in the recalculated estimates. However, these showed narrower ranges and lower values than the original ones and were concentration independent. The estimates of $r a$, calculated from the slurry incubations with ${ }^{15} \mathrm{NO}_{3}{ }^{-}$, were nearly the same as the corresponding values (A\%) calculated from the intact core measurements (Table 2). Consequently, the $\mathrm{N}_{2}$ production estimates derived using the 2 different calculation routines did not significantly differ from each other (Fig. 1). However, the slurry incubations with ${ }^{15} \mathrm{NH}_{4}{ }^{+}$and ${ }^{14} \mathrm{NO}_{3}{ }^{-}$ indicated a complete lack of anammox in the samples. Due to the low number of samples ( 3 for each treatment), caused by the unexpectedly fast disappearance of the added $\mathrm{NO}_{3}{ }^{-}$, the results of the slurry incubations are speculative and must be taken only as support for the results calculated from the r-IPT. The lack of ${ }^{29} \mathrm{~N}_{2}$ production from ${ }^{15} \mathrm{NH}_{4}{ }^{+}$and ${ }^{14} \mathrm{NO}_{3}{ }^{-}$challenges the idea of anammox as a factor explaining the detected D14 concentration dependency in the Gulf of Finland. However, the fast disappearance of the added $\mathrm{NO}_{3}{ }^{-}$ points out yet another process, dissimilatory nitrate
Table 2. Comparison of the results from the revised isotope pairing technique (r-IPT) and slurry incubations combined with r-IPT, to the classical IPT: the concentration of ${ }^{15} \mathrm{NO}_{3}{ }^{-}$ used in the measurements, the contribution of anammox to the total $\mathrm{N}_{2}$ production, measured with r-IPT (A\%) and from slurry incubations (ra), and the difference between the corrected and classical IPT $\mathrm{N}_{2}$ production estimate, as a percentage of the new estimate (Error\%). (No anammox at the inner estuary Stn AHLA)

\begin{tabular}{|c|c|c|c|c|c|c|}
\hline \multirow[t]{2}{*}{ Stn } & \multirow[t]{2}{*}{ Time } & \multirow{2}{*}{$\begin{array}{c}{ }^{15} \mathrm{NO}_{3}{ }^{-} \\
(\mu \mathrm{M})\end{array}$} & \multicolumn{2}{|c|}{ r-IPT } & \multicolumn{2}{|c|}{ Slurry+r-IPT } \\
\hline & & & $\mathrm{A} \%$ & Error\% & ra & Error\% \\
\hline \multirow[t]{3}{*}{ JML } & Jul 97 & 100 & 17.1 & 67 & & \\
\hline & & 150 & 16.6 & 267 & & \\
\hline & & 200 & 14.2 & 458 & & \\
\hline \multirow{3}{*}{ GF2 } & Jul 97 & 30 & 21.6 & 15 & & \\
\hline & & 100 & 19.9 & 183 & & \\
\hline & & 200 & 20.0 & 326 & & \\
\hline \multirow[t]{3}{*}{ GF2-B } & Apr 04 & 50 & 19.8 & 28 & 17 & 19 \\
\hline & & 100 & 13.7 & 52 & 17 & 45 \\
\hline & & 200 & 12.2 & 87 & 17 & 114 \\
\hline \multirow[t]{3}{*}{ GF2-K } & Apr 04 & 50 & 6.7 & 28 & 7 & 15 \\
\hline & & 100 & 6.9 & 49 & 7 & 19 \\
\hline & & 200 & 4.6 & 27 & 7 & 63 \\
\hline \multirow{3}{*}{ AHLA } & Aug 04 & 50 & (3.9) & (8) & (1) & (1) \\
\hline & & 100 & (8.9) & $(-3)$ & (1) & (2) \\
\hline & & 200 & (6.7) & $(-17)$ & (1) & (3) \\
\hline
\end{tabular}

reduction to ammonium (DNRA), as a possible cause for the conflicting results.

\section{Effect of DNRA in the slurry incubations with added ${ }^{15} \mathrm{NO}_{3}{ }^{-}$}

The added ${ }^{15} \mathrm{NO}_{3}{ }^{-}$disappeared from the slurry incubation vials 3 to 30 times faster than labelled $\mathrm{N}_{2}$ was produced (Fig. 2). The added ${ }^{15} \mathrm{NO}_{3}{ }^{-}$may have adsorbed to the sediment particles, been assimilated by sediment bacteria, or been reduced to ammonium in DNRA. The latter is usually considered to be of minor importance in natural sediments and to occur mainly in organically enriched environments, such as fish farm sediments (Hattori 1983, Christensen et al. 2000). However, Karlson et al. (2005) found that DNRA represented a major pathway of nitrate removal in laboratory experiments in which reduced Baltic Sea sediments were used. In addition, anammox bacteria were recently shown to convert nitrate to ammonium, even in the presence of external ammonium (Kartal et al. 2007). A significant DNRA rate would bias the anammox calculations based on the added ${ }^{15} \mathrm{NO}_{3}{ }^{-}$. Anammox should only produce ${ }^{29} \mathrm{~N}_{2}$ from the added ${ }^{15} \mathrm{NO}_{3}{ }^{-}$ and the naturally occurring ${ }^{14} \mathrm{NH}_{4}{ }^{+}$. The ${ }^{15} \mathrm{NH}_{4}{ }^{+}$emerging from DNRA would also enable ${ }^{30} \mathrm{~N}_{2}$ production by anammox from ${ }^{15} \mathrm{NO}_{3}{ }^{-}$and ${ }^{15} \mathrm{NH}_{4}{ }^{+}$. Assuming that the difference between the $\mathrm{N}_{2}$ production and $\mathrm{NO}_{3}{ }^{-}$reduction in the measurements reported here is DNRA, 94, 
75 and $55 \mu \mathrm{M}$ of ${ }^{15} \mathrm{NH}_{4}{ }^{+}$were produced at Stns GF2-B, GF2-K and AHLA, respectively, during the incubation. Using the adsorption coefficients measured for the $\mathrm{NH}_{4}{ }^{+}$in the slurry incubations $(2.4,1.2$ and 2.0$)$ and the total $\mathrm{NH}_{4}{ }^{+}$concentration measured in the samples (Fig. 2) gives the labelling percentage of the $\mathrm{NH}_{4}{ }^{+}$pool at the end of the incubations as $52 \%$ at Stn GF2-B, $72 \%$ at GF2-K and $11 \%$ at AHLA. This would result in severe underestimates of anammox, as the ${ }^{30} \mathrm{~N}_{2}$ production by anammox would be falsely interpreted as denitrification. Consequently, the true $\mathrm{N}_{2}$ production rate would be overestimated. As DNRA was not directly measured, the extent of the bias in the rates cannot be calculated, and these values must be seen as the highest errors possible. Some support for the speculation of a DNRA-based bias can be seen in the ${ }^{29} \mathrm{~N}_{2} /{ }^{30} \mathrm{~N}_{2}$ ratio in the slurry incubations with ${ }^{15} \mathrm{NO}_{3}{ }^{-}$ (Fig. 2). At Stn GF2-B, the ratio decreased toward the end of the incubation, indicating increased production of ${ }^{30} \mathrm{~N}_{2}$ at the expense of ${ }^{29} \mathrm{~N}_{2}$. The same effect, but to a lesser extent, can be seen at Stn GF2-K, but not at Stn AHLA, where no anammox was found. Also, the concentration of $\mathrm{NH}_{4}{ }^{+}$increased at the GF2 stations (but not at Stn AHLA) throughout the incubation, although as the ${ }^{15} \mathrm{NH}_{4}{ }^{+}$labelling percentage was not measured, it is not possible to confirm whether it originated from the DNRA of the added ${ }^{15} \mathrm{NO}_{3}{ }^{-}$, or from the mineralising of the natural $\mathrm{N}$ compounds in the sediment.

\section{Effect of DNRA in the slurry incubations with added ${ }^{15} \mathrm{NH}_{4}{ }^{+}$and ${ }^{14} \mathrm{NO}_{3}{ }^{-}$}

The production of ${ }^{29} \mathrm{~N}_{2}$ only in the slurry incubation with added ${ }^{15} \mathrm{NH}_{4}{ }^{+}$and ${ }^{14} \mathrm{NO}_{3}{ }^{-}$is considered to prove the existence of the anammox process in the sediment, and the lack of ${ }^{29} \mathrm{~N}_{2}$ production therefore indicates a lack of the process. However, DNRA may cause misinterpretations of the data here as well. In the experiments reported here, the added ${ }^{14} \mathrm{NO}_{3}{ }^{-}$disappeared from the vials extremely fast (Fig. 2). It could have been denitrified to ${ }^{28} \mathrm{~N}_{2}$, or reduced to ${ }^{14} \mathrm{NH}_{4}{ }^{+}$, as practically none of it was recovered as ${ }^{29} \mathrm{~N}_{2}$. In the slurry incubations with added ${ }^{15} \mathrm{NO}_{3}^{-}$, the calculated denitrification rate varied from 0.2 to $5.1 \mu \mathrm{M} \mathrm{N} \mathrm{h}^{-1}$, which is not high enough to explain the disappearance rate of the added ${ }^{14} \mathrm{NO}_{3}{ }^{-}$at any of the stations studied. Whether it is denitrification or DNRA that removes ${ }^{14} \mathrm{NO}_{3}{ }^{-}$from the samples, the outcome is the same, i.e. no ${ }^{29} \mathrm{~N}_{2}$ production high enough to be measurable. Assuming that in the incubations with added ${ }^{15} \mathrm{NH}_{4}{ }^{+}$and ${ }^{14} \mathrm{NO}_{3}{ }^{-}$both denitrification and anammox were proceeding at rates similar to those measured in the ${ }^{15} \mathrm{NO}_{3}{ }^{-}$incubations, and using the measured labelling percentage of the ${ }^{15} \mathrm{NH}_{4}{ }^{+}(70 \%)$ in the calculations, anammox should have produced $14 \mathrm{nM}{ }^{29} \mathrm{~N}_{2}$ at Stn GF2-B and $28 \mathrm{nM}$ ${ }^{29} \mathrm{~N}_{2}$ at Stn GF2-K during the first incubation hour when ${ }^{14} \mathrm{NO}_{3}{ }^{-}$was still available. Although the accuracy of the isotope ratio mass spectrometry is high $(0.0001 \%$ for ${ }^{29} \mathrm{~N}_{2}$ and $0.001 \%$ for ${ }^{30} \mathrm{~N}_{2}$ of the total $\mathrm{N}_{2}$, Nielsen 1992), the method may still not be sensitive enough to detect such small changes in concentrations, as can be seen in the decreasing values over time at Stn GF2-B. The total concentration of labelled compounds is higher in incubations with ${ }^{15} \mathrm{NO}_{3}{ }^{-}$, increasing the accuracy, as both denitrification and anammox participate in producing labelled $\mathrm{N}_{2}$. Therefore, the failure to prove the existence of the anammox process in the slurry incubations with added ${ }^{15} \mathrm{NH}_{4}{ }^{+}$and ${ }^{14} \mathrm{NO}_{3}{ }^{-}$can either mean that the process really does not exist in the sediments, or that it cannot be measured reliably using such a setup in sediments that express DNRA activity.

\section{Effect of DNRA in the IPT}

In the IPT, ${ }^{15} \mathrm{NO}_{3}{ }^{-}$is added to the water overlying the sediment in the intact sediment cores. From there it diffuses to the $\mathrm{NO}_{3}{ }^{-}$reducing zone in the anoxic sediment, where it can be denitrified, used in the anammox process or reduced to ${ }^{15} \mathrm{NH}_{4}{ }^{+}$in DNRA. As in the slurry incubations with added ${ }^{15} \mathrm{NO}_{3}{ }^{-}$, the ${ }^{15} \mathrm{NH}_{4}{ }^{+}$emerging from DNRA would enable ${ }^{30} \mathrm{~N}_{2}$ production by anammox and result in an underestimate of anammox and an overestimate of the true $\mathrm{N}_{2}$ production rate. In the slurry measurements, the added ${ }^{15} \mathrm{NO}_{3}{ }^{-}$disappeared completely in less than $3 \mathrm{~h}$. Time-series measurements made in the Gulf of Finland sediments earlier showed that the denitrification rate is independent of the incubation time at the open sea stations JML (mouth of the Gulf of Finland) and F41 (eastern Gulf of Finland) at least for $5 \mathrm{~h}$ (Tuominen et al. 1998), and at the coastal station in the northern Gulf of Finland (Tvärminne Storfjärden) at least for 6 h (S. Hietanen \& J. Kuparinen unpubl.). These findings suggest that DNRA did not affect $\mathrm{NO}_{3}{ }^{-}$availability or the ${ }^{14} \mathrm{NO}_{3}{ }^{-} /{ }^{15} \mathrm{NO}_{3}{ }^{-}$ratio in the $\mathrm{NO}_{3}{ }^{-}$reducing layer at the time of the measurements. At Stn GF1 (central Gulf of Finland), large variation in the results was found after $5 \mathrm{~h}$ of incubation (Tuominen et al. 1998). Such variation may have been caused by decreasing oxygen concentration, affecting the ${ }^{14} \mathrm{NO}_{3}{ }^{-}$production by nitrification, or by DNRA, lowering the availability of the $\mathrm{NO}_{3}{ }^{-}$.

\section{Significance of anammox in Gulf of Finland sediments}

In the experiments reported here, the existence of anammox in sediments of the Gulf of Finland could not 
be proven beyond doubt, and neither could it be dismissed, except in the coastal station where no indication of anammox was found. All factors recognised to possibly cause errors in the measurements bias the results toward underestimating the process rather than exaggerating it. Therefore, according to the prudence principle, it seems reasonable to assume that anammox does exist in these sediments. The discovery of anammox in the Gulf of Finland has larger ramifications for our view of the $\mathrm{N}$ budget of the gulf than one would expect from the low activity detected. The coexistence of anammox and denitrification leads to overestimates of the $\mathrm{N}_{2}$ production when measured using the IPT. This overestimation is positively related to the concentration of ${ }^{15} \mathrm{NO}_{3}{ }^{-}$added to the system (RisgaardPetersen et al. 2003). Since the mid-1990s, denitrification has been measured in situ as well as in laboratory experiments from sediments of the northern Baltic Sea, using the isotope pairing technique (Tuominen et al. 1998, 1999, Gran \& Pitkänen 1999, Autio et al. 2003, S. Hietanen \& J. Kuparinen unpubl.). In these measurements, a high concentration of ${ }^{15} \mathrm{NO}_{3}{ }^{-}$was used, based on the paper by Tuominen et al. (1998). In this paper, it was stated that denitrification was saturated at $100 \mu \mathrm{M}$ of ${ }^{15} \mathrm{NO}_{3}{ }^{-}$in the water above the sediment, and that using such an admittedly high concentration did not change the first-order kinetics of denitrification, as could be seen from the linear increase of D15 ( $\mathrm{N}_{2}$ production based on the labelled nitrate) along the increased incubation concentration. These measurements, made before the discovery of anammox in marine sediments, were made to verify that the ${ }^{14} \mathrm{NO}_{3}{ }^{-}$ was efficiently combined with ${ }^{15} \mathrm{NO}_{3}{ }^{-}$, hence confirming that there was no underestimation of the denitrification rate due to non-uniform mixing of the isotopes, caused by heterogeneity of the sediment (Nielsen 1992). The measured coupled nitrification-denitrification was plotted against the incubation concentration, but not statistically analysed, and the deviations from the line were either explained by the lack of oxygen or simply omitted as technical problems due to the lack of a theoretical explanation. In the present study, anammox was detected in both open sea basins studied and explained the concentration dependency of the D14 estimate. Consequently, it is likely that denitrification rates have been overestimated in the Gulf of Finland and that this overestimation may have been substantial due to the high ${ }^{15} \mathrm{NO}_{3}{ }^{-}$concentrations used (Figs. 1 \& 3, Table 2). In upcoming research, the contribution of anammox must be taken into account, at least by doing the concentration series measurements, as suggested by Risgaard-Petersen et al. (2003). The high natural variability in the Baltic Sea accumulation sediments, already at the cm scale (Tuominen et al. 1998), obviously calls for numerous replicates in the measurements in order to make reliable estimates. The recently published direct technique, based on ${ }^{15} \mathrm{~N}$ labelling of the $\mathrm{N}_{2} \mathrm{O}$, enables denitrification and anammox to be measured in intact cores even in highly heterogeneous sediments (Trimmer et al. 2006). Therefore, although adding a rather complicated analytical procedure to the basic IPT, this new application may become the method of choice in future research on $\mathrm{N}_{2}$ production in natural sediments. In addition to measuring the rates, the existence of anammox bacteria should be confirmed using biomarkers such as ladderane lipids typical of these bacteria or by molecular ecology. Both of these approaches have recently been reviewed by Schmid et al. (2005).

As no data about the seasonal and spatial variability of the anammox rates from the Gulf of Finland are yet available, the true $\mathrm{N}_{2}$ production rates cannot be reliably estimated. Both the $\mathrm{N}$ budgets and models, however, indicate that some $70000 \mathrm{t} \mathrm{N}$ should be removed from the gulf annually (Perttilä et al. 1995, Kiirikki et al. 2006). This corresponds to a rate of about $450 \mu \mathrm{mol}$ $\mathrm{N} \mathrm{m}^{-2} \mathrm{~d}^{-1}$, which is high compared to the $\mathrm{N}_{2}$ production rates measured here. However, the high spatial and temporal variability in the sediment processes, caused by heterogeneity in the bottom topography, flow rates, environmental conditions and inter-annual changes in these, leave room for speculation. Obviously, there are still large gaps in our understanding of the $\mathrm{N}$ dynamics in the Gulf of Finland. As some of the highest $\mathrm{N}_{2}$ production values have been measured from coastal and river estuarine basins, these seem

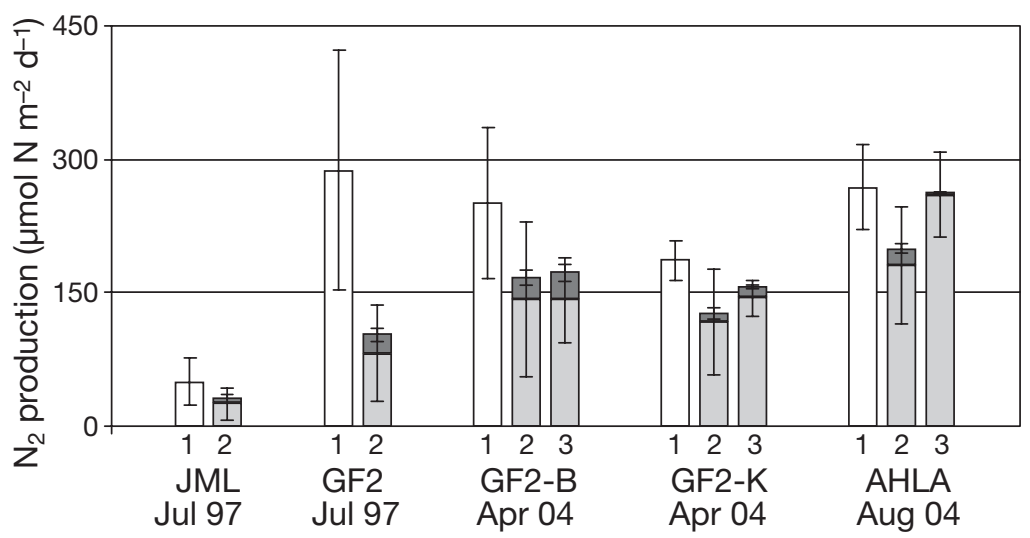

Fig. 3. $\mathrm{N}_{2}$ production (mean $\pm \mathrm{SD}$ ) at an incubation concentration of $100 \mu \mathrm{M}$ ${ }^{15} \mathrm{NO}_{3}{ }^{-}$, which is commonly used in Gulf of Finland denitrification measurements, calculated using 3 different approaches: (1) IPT (white columns), (2) r-IPT, and (3) slurry incubations combined with r-IPT (denitrification: light grey columns, anammox: dark grey columns) 
likely places to begin searching for the 'mysteriously disappearing $N^{\prime}$. Future research should include at least measurements at shallow basins and transportation sediments, as well as seasonal dynamics of the river estuary $\mathrm{N}_{2}$ production. These may yet prove to be the sites of more active $\mathrm{N}_{2}$ production than the accumulation basins studied to date.

Acknowledgements. This study was funded by the Academy of Finland BIREME programme and conducted in the SEGUE consortium. I thank the Finnish Institute of Marine Research for the original IPT data from 1997, and Dr. P. Engström and 2 anonymous reviewers for constructive comments on an earlier version of the manuscript.

\section{LITERATURE CITED}

Autio L, Mäkelä K, Lehtonen KK, Kuparinen J, Haahti H (2003) Effects of algal sedimentation and Monoporeia affinis on nutrient fluxes, pore water profiles and denitrification in sediment microcosms. Boreal Environ Res 8: 229-243

Christensen PB, Rysgaard S, Sloth NP, Dalsgaard T, Schwærter S (2000) Sediment remineralization, nutrient fluxes, denitrification and dissimilatory nitrate reduction in an estuarine fjord with sea cage trout farms. Aquat Microb Ecol 21:73-84

Dalsgaard T, Thamdrup B (2002) Factors controlling anaerobic ammonium oxidation with nitrite in marine sediments. Appl Environ Microbiol 68:3802-3808

Dalsgaard T, Thamdrup B, Canfield DE (2005) Anaerobic ammonium oxidation (anammox) in the marine environment. Res Microbiol 156:457-464

Gran V, Pitkänen H (1999) Denitrification in estuarine sediments in the eastern Gulf of Finland, Baltic Sea. Hydrobiologia 393:107-115

Hattori A (1983) Denitrification and dissimilatory nitrate reduction. In: Carpenter E, Capone DB (eds) Nitrogen in the marine environment. Academic Press, San Diego, CA, p 191-232

HELCOM (Helsinki Commission) (2002) Fourth periodic assessment of the state of the marine environment of the Baltic Sea 1994-1998. Balt Sea Environ Proc 82A:1-215

Hietanen S, Kuparinen J (in press) Seasonal and short-term variation in dentrification and anammox at a coastal station on the Gulf of Finland, Baltic Sea. Hydrobiologia

Karlson K, Hulth S, Ringdahl K, Rosenberg R (2005) Experimental recolonisation of Baltic Sea reduced sediments: survival of benthic macrofauna and effects on nutrient cycling. Mar Ecol Prog Ser 294:35-49

Kartal B, Kuypers MMM, Lavik G, Schalk J, Op den Camp HJM, Jetten MSM, Strous M (2007) Anammox bacteria disguised as denitrifiers: nitrate reduction to dinitrogen gas via nitrite and ammonium. Environ Microbiol 9:635-642

Kiirikki M, Rantanen P, Varjopuro R, Leppänen A and 7 others (2003) Cost effective water protection in the Gulf of Finland. Focus on St. Petersburg. The Finnish Environment 632. Edita Publishing, Vantaa

Kiirikki M, Lehtoranta J, Inkala A, Pitkänen $\mathrm{H}$ and 5 others (2006) A simple sediment process description suitable for 3D-ecosystem modelling - Development and testing in the Gulf of Finland. J Mar Syst 61:55-66

Kivi K, Kaitala S, Kuosa H, Kuparinen J, Leskinen E, Lignell
R, Marcussen B, Tamminen T (1993) Nutrient limitation and grazing control of the Baltic plankton community during annual succession. Limnol Oceanogr 38:893-905

Koroleff F (1983) Determination of ammonia. In: Grasshoff K, Ehrhardt M, Kremling K (eds) Methods of sea water analysis, 2nd edn. Verlag Chemie, Weinheim, p 150-157

Mäkelä K, Tuominen L (2003) Pore water nutrient profiles and dynamics in soft bottoms of the northern Baltic Sea. Hydrobiologia 492:43-53

Mulder A, van de Graaf AA, Robertson LA, Kuenen JG (1995) Anaerobic ammonium oxidation discovered in a denitrifying fluidized-bed reactor. FEMS Microbiol Ecol 16: $177-183$

Nielsen LP (1992) Denitrification in sediment determined from nitrogen isotope pairing. FEMS Microbiol Ecol 86: $357-362$

Perttilä M, Niemistö L, Mäkelä K (1995) Distribution, development and total amounts of nutrients in the Gulf of Finland. Estuar Coast Shelf Sci 41:345-360

Pitkänen H, Tamminen T (1995) Nitrogen and phosphorus as production limiting factors in the estuarine waters of the eastern Gulf of Finland. Mar Ecol Prog Ser 129:283-294

Pitkänen H, Lehtoranta J, Räike A (2001) Internal nutrient fluxes counteract decreases in external load: the case of the estuarial eastern Gulf of Finland, Baltic Sea. Ambio 30: 195-201

Risgaard-Petersen N, Nielsen LP, Rysgaard S, Dalsgaard T, Meyer RL (2003) application of the isotope pairing technique in sediment where anammox and denitrification coexist. Limnol Oceanogr Methods 1:63-73

Risgaard-Petersen N, Nielsen LP, Rysgaard S, Dalsgaard T, Meyer RL (2004) Erratum: Application of the isotope pairing technique in sediment where anammox and denitrification coexist. Limnol Oceanogr Methods 2:315

Schmid MC, Maas B, Dapena A, van de Pas-Schoonen K and 13 others (2005) Biomarkers for in situ detection of anaerobic ammonium-oxidizing (Anammox) bacteria. Appl Environ Microbiol 71:1677-1648

Thamdrup B, Dalsgaard T (2002) Production of $\mathrm{N}_{2}$ through anaerobic ammonium oxidation coupled to nitrate reduction in marine sediments. Appl Environ Microbiol 68: 1312-1318

Trimmer M, Nicholls JC, Deflandre B (2003) Anaerobic ammonium oxidation measured in sediments along the Thames estuary. Appl Environ Microbiol 69:6447-6454

Trimmer M, Risgaard-Petersen N, Nicholls JC, Engström P (2006) Direct measurements of anaerobic ammonium oxidation (anammox) and denitrification in intact sediment cores. Mar Ecol Prog Ser 326:37-47

Tuominen L, Heinänen A, Kuparinen J, Nielsen LP (1998) Spatial and temporal variability of denitrification in the sediments of the northern Baltic Proper. Mar Ecol Prog Ser 172:13-24

Tuominen L, Mäkelä K, Lehtonen KK, Haahti H, Hietanen S, Kuparinen J (1999) Nutrient fluxes, pore water profiles and denitrification in sediment influenced by algal sedimentation and bioturbation by Monoporeia affinis. Estuar Coast Shelf Sci 49:83-97

Vahtera E, Conley DJ, Gustafsson BG, Kuosa H and 7 others (2007) Internal ecosystem feedbacks enhance nitrogenfixing cyanobacteria blooms and complicate management in the Baltic Sea. Ambio 36:186-194

Van de Graaf AA, Mulder A, de Bruijn P, Jetten MSM, Robertson LA, Kuenen JG (1995) Anaerobic oxidation of ammonium is a biologically mediated process. Appl Environ Microbiol 61:1246-1250 